удК 339.138

\title{
ВИКОРИСТАННЯ ДІДЖИТАЛ-МАРКЕТИНГУ У КОМПЛЕКСІ ПРОСУВАННЯ
}

\section{USE OF DIGITAL MARKETING IN THE PROMOTION COMPLEX}

\author{
Гарматюк Олена Валентинівна \\ старший викладач, \\ Уманський державний педагогічний університет імені Павла Тичини \\ ORCID: https://orcid.org/0000-0002-2589-3269
}

Garmatyuk Olena

Uman State Pedagogical University named after Pavel Tychyna

\begin{abstract}
У статті актуалізовано питання digital-маркетингу. Розкрите питання щодо сутності поняття «digitalмаркетинг». Обґрунтована відповідь щодо відмінностей «цифрового маркетингу» та «маркетингу в інтернеті». Присутня розгорнута відповідь, на питання: «що $є$ основними інструментами digital-маркетингу та каналами його розподілу». Наведені приклади реалізації декількох з перелічених каналів. Обґрунтована принципова відмінність сучасних засобів digital-маркетингу від минулих, які наразі не мають такої високої ефективності, як раніше. До інструментів digital-маркетингу відносяться заходи, які дозволяють оповістити велика кількість людей або привернути увагу цільової аудиторії до продукції або послуг компанії, організації. дається характеристика основних ефективних інтегрованих інструментів digital-маркетингу. Особливу увагу відведено ефективності соціальних медіа каналів. Автором проведено SWOT-аналіз, який допоміг визначити сильні та слабкі сторони використання digital-маркетингу. На основі отриманої інформації зроблені аргументовані висновки.

Ключові слова: digital-маркетинг, інструменти digital-маркетингу, канали digital-маркетингу, інтернет, реклама.
\end{abstract}

В статье актуализирован вопрос digital-маркетинга. Раскрыто вопрос о сущности понятия «digitalмаркетинг». Обоснованный ответ по отличий «цифрового маркетинга» и «маркетинга в интернете». Присутствует развернутый ответ на вопрос: «что являются основными инструментами digital-маркетинга и каналами его распределения». Приведенные примеры реализации нескольких из перечисленных каналов. Обоснована принципиальная разница современных средств digital-маркетинга от прошлых, которые пока не имеют такой высокой эфффективности, как раньше. К инструментам digital-маркетинга относятся меры, которые позволяют оповестить большое количество людей или привлечь внимание целевой аудитории к продукции или услуг компании, организации. дается характеристика основных эффеективных интегрированных инструментов digital-маркетинга. Особое внимание отведено эфрфективности социальных медиа каналов. Автором проведен SWOT-анализ, который помог определить сильные и слабые стороны использования digital-маркетинга. На основе полученной информации сделаны аргументированные выводы.

Ключевые слова: digital-маркетинг, инструменты digital-маркетинга, каналы digital-маркетинга, интернет, реклама.

The article actualizes the issue of digital marketing. The question of the essence of the concept of «digital marketing» is revealed. The answer to the differences between «digital marketing» and «Internet marketing» is substantiated. There is a detailed answer to the question: «what are the main tools of digital marketing and channels of its distribution». Examples of implementation of several of the listed channels are given. The advantages and disadvantages of their use of digital marketing are determined, as well as criteria for evaluating the effectiveness. The advantages and disadvantages of digital marketing are considered in the form of SWOT-analysis. The fundamental difference between modern digital marketing tools from the past, which are not as effective as before, is substantiated. Digital marketing tools include activities that allow you to alert a large number of people or draw the attention of the target audience to the products or services of the company, organization. gives a description of the main effective integrated tools of digital marketing. Particular attention is paid to the effectiveness of social media channels. A special place in the article is devoted to an overview of digital marketing channels and tools. Digital Marketing, like digital communications, is targeted and interactive in nature. Digital media (or new media) is a complex of digital carriers of advertising messages. Held comparison of the main groups of media channels. The author offers 
his own classification of digital tools. The peculiarity of this classification is that it will allow you to navigate in the Digital environment, regarding user behavior and use the most effective tools in a specific situation and a specific task to attract. Over time, the classification of tools proposed by the author can be supplemented with new, more effective tools. The practical importance of this work lies in the possibility of further use of the research results (in particular, the formed assessment of digital tools) and taking them into account when developing integrated bathroom marketing communications. On the basis of the received information the reasoned conclusions are made.

Keywords: digital marketing, digital marketing tools, digital marketing channels, internet, advertising.

Постановка проблеми у загальному вигляді. Цифрова економіка яка швидко розвивається вимагає перегляду актуальності існуючих маркетингових практик, і виникає необхідність кардинальних змін маркетингових програм, які будуть відповідати новим потребам бізнесу XXI століття. Оскільки всі мимоволі занурені в цифрову еру. Розвиток інформаційного суспільства, смартекономіки, процесів глобалізації породжують необхідність використання digital-маркетингу, при цьому сама парадигма digital-маркетинг постійно розвивається, створюючи умови для успішного розвитку і конкурентного позиціонування бізнесу його використання $€$ найеорективнішим інструментом для охоплення потенційних споживачів. Тому так актуальна тема дослідження, яка присвячена питанням впровадження digital-маркетингу, визначенням його сильних та слабких сторін.

Аналіз останніх досліджень та публікацій. Вагомий внесок у розвиток digitalмаркетингу внесли: Р. Акерман, А. Керолл, Ф. Котлер, Л. Престон та інші. Проте, це поняття все ще потребує подальшого більш глибокого дослідження його змін на сучасному етапі.

Формулювання цілей статті (постановка завдання). Метою статті $€$ визначення сутності поняття «digital-маркетинг», виявлення його переваг та недоліків. Проведення чіткої лінії, що відмежує поняття «цифровий маркетинг» і «маркетинг в інтернеті».

Виклад основного матеріалу статті. Цифрровий маркетинг (з англ. digital marketing) - це використання всіх можливих фрорм цифрових каналів для просування бренда [1]. Це загальний термін для маркетингу товарів і послуг, який використовує цифрові канали для залучення і утримання клієнтів. Причому будь-які - від реклами на онлайн радіо до оголошення контекстної реклами в інтернеті. Говорячи простими словами, digitalмаркетинг - це будь-яке просування, в якому бере участь «цифра».

Доволі таки часто поняття «digital маркетинг» плутають 3 інтернет маркетингом, але в них є суттєва відмінність. Вірніше, digital- маркетинг включає в себе і інтернет-маркетинг теж, але інтернетом не обмежується.

Давайте порівняємо: інтернет-маркетинг це SEO-просування сайту, контекст, вебінари і т.п. Це всі канали, які доступні користувачеві тільки в інтернеті [2]. A digital-маркетинг це все вище перелічене плюс реклама і просування на будь-яких цифррових носіях поза мережею. Тобто, він має на увазі цифррову комунікацію, яка відбувається і онлайн, і офллайн. Ну і зрозуміло, що до digital-маркетингу не належить просування за допомогою таких традиційних каналів як оголошення в газетах, фрлаєра, реклама на ТБ, білборди. Хоча, якщо на білборді буде вказано QR-код, за допомогою якого можна перейти на сайт - то це вже digital-маркетинг.

Основними інструментами digital-маркетингу є наступні:

- Контекстна реклама. Вона полягає в розміщенні рекламних оголошень (текстових, графрічних і/або у вигляді посилань) на тематичних сайтах.

- SEO-просування. Його метою є підняття сайту рекламодавця у видачі по тематичних запитах, для чого виконується пошукова оптимізація та ін.

- Банерна реклама. На сторонніх тематичних ресурсах здійснюється розміщення графрічних банерів 3 пропозицією продукту/ послуги.

- Рекламні вікна. Це спосіб інтернетреклами, що має на увазі показ спливаючих рекламних вікон на тематичних площадках в інтернеті [3].

Канали digital-маркетингу: e-mail-маркетинг; партнерський маркетинг; соціальні мережі; дисплейна або медійна реклама; пошуковий маркетинг; відеоігри; відеореклама; інфрографріка.

За іншою ж класифрікацією канали digitalмаркетингу можна структурувати наступним чином: соціальні мережі; термінали самообслуговування; інтерактивні екрани; POSтермінали; веб-сайти; ігрові консолі; офрлайн магазини; комп'ютери та планшети; циорове телебачення; мобільні додатки; смартфони; локальні мережі; гаджети. 
Зважаючи на кількість каналів в digitalмаркетингу, слід також навести приклади реалізації деяких із них.

1. Циярове телебачення. Сучасне телебачення дуже відрізняється від того, що було років 15-10 назад. Зараз з його допомогою можна скористатись інтернетом, відвідати свою сторінку в соціальній мережі, або ж переглянути електронну пошту. I це лише маленька частинка того, на що спроможні сучасні технології, а також верхівка айсберга digital-маркетингу, задача котрого полягає у використанні цифррових технологій для залучення нових клієнтів, та утримування наявних.

2. Digital гаджети. В цю категорію цікавих, а головне корисних новинок, можна віднести фрітнес браслети, що зможуть есрективно слідкувати за кількістю кроків які ви пройшли за день та кількістю затрачених на це калорій. Вони зможуть моніторити ваш пульс в режимі реального часу та повідомити, при наявності небезпеки для здоров'я. В подальшому, інфрормація що отримують гаджети, завантажується на телефони чи комп'ютери.

3. Digital art. Це вид мистецтва, в якому гаджети використовуються для створення витвору мистецтва. Ним може бути: малюнок, мелодія, відео, анімація, гра, веб-сайт та інсталяція.

Коли мова заходить про SEO, не завжди зрозуміло, з чого краще почати. До того ж, можна легко витратити купу часу на те, що принесе лише невеликий результат. Це не нова проблема, і стосується вона не тільки тактик традиційного маркетингу, але і сучасних digital-активностей.

Як і у інших видах маркетингу, у digitalмаркетингу $€$ свої переваги та недоліки, які будуть нами розглянуті у вигляді SWOTаналізу (табл. 1).

Слід деталізувати дані представлені в таблиці 1.

Основними загрозами є людський фрактор. Реклама на сайтах, додатках, месенджерах та онлайн іграх сприймається по різному, але стереотип «набридливої реклами» все ще має місце і по цей день. Тому навіть якщо додатки рекламують послуги своїх спонсорів вже й не так жваво як раніше, а на зміну звичайної, прийшла контекстна реклама, частина людей все ще відноситься до неї негативно. Деякі люди просто ігнорують таку рекламу, або встановлюють спеціальні додатки, що блокують іï, наприклад (adblock). Інша ж частина населення, завдяки рекламі та рекламним розсилкам знаходить саме те, що шукала, тут все суто індивідуально.

ще однією з причин що стають на шляху digital-маркетингу та обмежують його потенціал є мінливість зовнішнього середовища, до змін в якому, досить важко пристосуватись. Ще кілька років тому були популярні звичайні мобільні телесрони 3 невеличким фрункціоналом, але на їх зміну прийшли сучасні смарторони 3 широким колом можливостей і безліччю додатків. Звичайно не всі в змозі пристосуватись до таких змін, і в результаті залишаються за бортом, а науковий прогрес не стоїть на місці.

Такі люди не зможуть в повній мірі оцінити digital-маркетинг. Вони не користуються цифрровим ТВ, не слухають online-радіо, а про рекламу в месенджерах і додатках й говорити годі. До такої категорії людей як правило належать люди похилого віку, малозабезпечені сім'ї та справжні роботяги у яких не вистачає

SWOT-аналіз digital-маркетингу

\begin{tabular}{|c|c|}
\hline Загрози (3) & Можливості (М) \\
\hline $\begin{array}{l}\text { 1. Людський фрактор. } \\
\text { 2. Мінливість. }\end{array}$ & $\begin{array}{l}\text { 1. Відсутність або обмеження } \\
\text { широкосмугового інтернет доступу у } \\
\text { потенційних споживачів цифррових послуг. }\end{array}$ \\
\hline Сильні сторони (Сi) & Слабкі сторони (Сл) \\
\hline $\begin{array}{l}\text { 1. Широка аудиторія. } \\
\text { 2. Цифрово технології допомагають надавати } \\
\text { більш серйозний вплив на клієнтів, що підвищує } \\
\text { ймовірність зацікавленості продуктом. } \\
\text { 3. Цифррове просування обходиться дешевше } \\
\text { інших стратегій. } \\
\text { 4. Цифровий маркетинг дозволяє охопити } \\
\text { і онлайн-, і офрлайн-споживачів. } \\
\text { 5. Можливість збирати чіткі і деталізовані дані. } \\
\text { 6. Гнучкий підхід. }\end{array}$ & $\begin{array}{l}\text { 1. Недолік обізнаності про цифррові } \\
\text { технології всередині компанії. } \\
\text { 2. Не можна зробити це "по-швидкому". } \\
\text { Не можна стати успішною digital- } \\
\text { компанією за 2-3 тижні. У багатьох йдуть } \\
\text { на це роки, в кращому випадку, місяці; } \\
\text { 3. Digital-маркетинг не можна уявити } \\
\text { 3 2-3 інструментів, які ви налаштували, } \\
\text { i вони будуть працювати. }\end{array}$ \\
\hline
\end{tabular}

Таблиця 1 
часу на розваги та серфрінг в інтернеті. Якщо фрінансова ситуація в країні зміниться в кращу сторону, то й частина $з$ людей цієї категорії зможе прилаштуватись до нового!

До можливостей доцільно віднести відсутність або обмеження широкосмугового інтернет доступу у потенційних споживачів цифрових послуг. Ця проблема обмежує поширення digital маркетингу в інтернеті та стримує його потенціал, який з розвитком технологій та доступності інтернету буде лише зростати. Вирішення цієї проблеми може стати прекрасною можливістю для компаній, що користуються digital-маркетингом.

Сильними сторонами виступає широка аудиторія - завдяки digital-маркетингу, можна взаємодіяти з більш широкою аудиторією, і відшукати клієнтів навіть у несподіваних місцях. Цифрровий маркетинг дозволяє охопити і онлайн-, і офрлайн-споживачів, які використовують планшети і мобільні телефони, грають в ігри, завантажують додатки. Так чином бренд може розширити свої можливості не обмежуючись інтернетом.

Можливість збирати чіткі і деталізовані дані. Практично всі дії користувача в циорровому середовищі фріксуються аналітичними системами. Що дозволяє робити точні висновки про ефективність різних каналів просування, а також скласти точний портрет покупця.

Гнучкий підхід - digital-маркетинг дозволяє залучити на онлайн-ринок офлайн аудиторію, i навпаки. Наприклад, за допомогою QR-коду на фрлаєрі можна направити користувача на сайт. I в той же час, завдяки email-розсилці можна запросити передплатників на семінар або інший офлайн-івент.

Слабкими сторонами Digital-маркетингу $€$ те, що його не можна уявити з 2-3 інструментів, які б ви налаштували, і вони будуть працювати. Треба завжди тримати руку на пульсі, щоб ефрективно реагувати на зміни зовнішнього середовища.

Digital-маркетинг розвивається, методи, які були популярні та ефрективні раніше, поступово будуть знижувати свою корисність порівняно 3 іншими. Так, крапельний маркетинг, лонгріди та ставка на SEO тексти більше не мають такої ефрективності як раніше. На даний момент біля 80\% трафріку займає відео-контент. Наразі, швидше та ефективніше знайти відео на тематику що цікавить вас, ніж шукати відповіді в книгах чи статтях в інтернеті.

Нові технології і стратегії дозволяють значно збільшити ефрективність маркетингу, особливо, якщо ви починаєте використовувати їх раніше своїх конкурентів. Нижче представлені тренди, які мають більшу ефективність, порівняно з вищеназваними.

1. Орієнтація на мобільні пристрої з геотаргетингом. Користувачі мобільних гаджетів запускають близько 75 окремих клієнтських сеансів щодня, що дорівнює приблизно трьом годинам екранного часу. Для digitalмаркетологів це означає 75 можливостей щодня безпосередньо взаємодіяти із споживачем. Саме тут може допомогти гео-таргетинг - процес розподілу або просування контенту користувачеві сайту на основі його геограсрічного місця розташування. Це особливо вигідно для компаній, у яких є вітрина. Наприклад, кафе може показувати «місцевим» відвідувачам спеціальну рекламну пропозицію в радіусі декількох км, щоб вони приходили саме до вас, а не купували каву у конкурентів.

Дослідження також показали, що при проведенні гео-таргетингових кампаній витрати зазвичай нижчі, а показники конверсії вищі, що забезпечує маркетологам максимально ефрективний бюджет.

2. Відео-контент. Відео у найближчому майбутньому почне виконувати фрункції пошуку. YouTube вже вважається другою за величиною пошуковою системою у світі. Створення облікового запису на YouTube i регулярне завантаження контенту не вимагає особливих зусиль, до того ж, воно абсолютно безкоштовне. Компанії часто намагаються догодити всім: вони використовують занадто багато облікових записів у соціальних мережах і не в змозі впоратися з зрозумілою та ефективною стратегією для кожного $з$ них. Отже, контент був і залишається центром результативного цифррового маркетингу, проте на початку поточного року намітилася тенденція до розвитку персоналізації для надання ефективного впливу [5, с. 38].

3. Мобільний світ. На даний час понад $60 \%$ користувачів здійснюють пошук в інтернеті за допомогою мобільних пристроїв: починаючи 3 використання соціальних медіа і закінчуючи онлайн покупками, банківськими послугами [4]. Все більше і більше користувачів довіряють своїм мобільним гаджетам, а кількість осіб, які використовують стаціонарні персональні комп'ютери - стрімко знижується.

Як результат, багато фрірм змінюють свої пріоритети, чому свідчить поява багатьох додатків, яким немає аналогів на персональному комп'ютері. Digital-маркетинг змінюється і розвивається, щоб відповідати запитам своїх споживачів. 
Висновки. Таким чином, сучасне значення маркетингу пов'язано з пошуком нових потреб і адаптацією виробництва і збуту до попиту для задоволення клієнтів. Це дозволяє виробляти товари і послуги більш високої якості і тим самим збільшувати свої продажі і прибуток від них. Завдяки digital-маркетингу, який повинен бути побудований логічно і оптимально, з'являється можливість поліпшення спілкування, зв'язків і взаємодії споживача і виробника. Тим самим відбувається персоналізація товарів чи послуг, яка дозволяє отримувати максимальні можливості у вигляді прибутку і нових зацікавлених клієнтів.

\section{СПИСОК ВИКОРИСТАНИХ ДЖЕРЕЛ:}

1. Васильців Н.М. Сучасні тренди digital-маркетингу. Електронне наукове фрахове видання. Економіка $i$ суспільство. 2018. Випуск 15. С. 232-236.

2. Коваль Н.B. Digital-маркетинг як інноваційний інструмент управління комунікаціями. URL: http://dspace.wunu.edu.ua/bitstream/316497/37880/1/152.pdf (дата звернення: 15.03.2021).

3. Digital-marketing. Рекламна агенція: Super Media. URL: https://www.s-media.com.ua/articles/entry/digitalmarketing (дата звернення: 18.03.2021).

4. Венгер €.I. Digital-маркетинг: сучасні тренди та переваги. Вісник Чернівецького торговельно-економічного інституту. Економічні науки. 2017. Вип. 4. С. 204-213.

5. Васильців Н.М. Цифровий маркетинг як складник перспективного напряму розвитку Індустрії 4.0. Електронне наукове фахове видання. Економіка і суспільство. 2019. № 2(64). С. 35-40.

\section{REFERENCES:}

1. Vasyltsiv N.M. (2018) Suchasni trendy didzhytal marketynhu-marketynhu [Modern trends in digital marketing]. Elektronne naukove fakhove vydannia. Ekonomika i suspilstvo, vol. 15, pp. 232-236.

2. Koval N.V. Didzhytal-marketynh yak innovatsiinyi instrument upravlinnia komunikatsiiamy [Digital marketing as an innovative communication management tool]. Retrieved from: http://dspace.wunu.edu.ua/bitstream/316497/37880/1/152.pdf (accessed 15 March 2021).

3. Reklamna ahentsiia: Super Media. Digital-marketing (unpublished). Retrieved from: https://www.s-media.com.ua/ articles/entry/digital-marketing (accessed 18 March 2021).

4. Venher Ye.I. (2017) Didzhytel-marketynh: cuchasni trendy ta perevahy [Digital marketing: current trends and benefits]. Visnyk Chernivetskoho torhovelno-ekonomichnoho instytutu. Ekonomichni nauky, vol. 4, pp. 204-213.

5. Vasyltsiv N.M. (2019) Tsyfrovyi marketynh yak skladnyk perspektyvnoho napriamu rozvytku Industrii 4.0. [Digital marketing as a constituent of the promising direction of industry 4.0 development]. Elektronne naukove fakhove vydannia. Ekonomika i suspilstvo, no. 4(64), pp. 35-40. 